\title{
Thyroxine and triiodothyronine concentrations during lactation in dairy cows
}

\author{
Ivan Pentchev Gueorguiev*
}

Department of Veterinary Physiology and Endocrinology, Faculty of Veterinary Medicine,
Thracian University, 6000 Stara Zagora, Bulgaria

(Received 1 October 1998; accepted 6 August 1999)

\begin{abstract}
The present study was conducted to investigate the behaviour of thyroid hormones in association with milk yield in early, at peak and in mid-lactation in dairy cows. Blood samples obtained from 45 lactating dairy cows in various stages of lactation were analysed by radioimmunoassay for thyroxine $\left(\mathrm{T}_{4}\right)$ and triiodothyronine $\left(\mathrm{T}_{3}\right)$. Milk yield and serum concentrations of $\mathrm{T}_{4}$ and $\mathrm{T}_{3}$ were recorded for early, mid- and peak stage of lactation. Thyroxine and triiodothyronine both exhibited similar profiles in response to stage of lactation. Concentrations in early and at peak lactation were significantly $(P<0.001)$ lower than in mid-lactation, when milk production markedly decreased. (@) Elsevier/Inra)
\end{abstract}

thyroxine / triiodothyronine / lactation / dairy cows

Résumé - Concentrations en thyroxine et triiodothyronine au cours de la lactation chez les vaches laitières. Les variations de concentrations sanguines en thyroxine $\left(T_{4}\right)$ et triiodothyronine $\left(T_{3}\right)$ ont été étudiées au cours de la lactation chez 45 vaches laitières. Les prélèvements sanguins ont été effectués en début, au pic et en milieu de lactation. La production laitière a également été mesurée pendant ces mêmes périodes. Les concentrations sériques en thyroxine et triiodothyronine déterminées en début et au pic de lactation sont significativement plus faibles qu'en milieu de lactation. Une corrélation négative entre les hormones thyroidiennes $\left(\mathrm{T}_{4}\right.$ et $\left.\mathrm{T}_{3}\right)$ et la production laitière a été mise en évidence. $(\odot$ Elsevier / Inra)

thyroxine / triiodothyronine / lactation / vaches laitières

* Correspondence and reprints

Tel.: 0035942 28012869; fax: $003594245101 / 003594274112$ 


\section{INTRODUCTION}

The pituitary thyroid axis is an important physiological factor controlling metabolic processes and milk secretion. Thyroid hormones (thyroxine $\left[\mathrm{T}_{4}\right]$ and triiodothyronine $\left[\mathrm{T}_{3}\right]$ ) synergize with other hormones to promote growth and development of the mammary gland and maintenance of lactation [2]. Injection of thyrotropin-releasing hormone or thyroxine moderately increases milk production in cows $[3,8]$. Galactopoietic effect of thyroid hormones is due to their direct and indirect influence on mammary gland metabolism, affecting mammary blood flow, nutrient partitioning and mammary secretion rate $[4$, 11]. Tiirats [10] reported that serum thyroid hormone concentration increased as the stage of lactation progressed, the values at the late stage of lactation being significantly higher compared with the early stage of lactation.

The present study was undertaken to investigate the behaviour of thyroid hormones in association with milk yield in early, at peak and in mid-lactation in lactating dairy cows.

\section{MATERIAL AND METHODS}

Experiments were carried out during the summer season with 45 lactating cows of the Bulgarian Black and White breed in their third to fifth lactation. The animals were divided into three groups of 15 each for stage of lactation measurements. Cows were kept at the Experimental University Station and were fed and milked according to the normal regimen of the herd. The total ration was balanced for body maintenance and milk production requirements. Their basic diet consisted of alfalfa hay $(25 \mathrm{~kg})$, maize silage $(10 \mathrm{~kg})$ and brewers grains $(10 \mathrm{~kg})$. All cows were fed the mixed concentrates $(15 \%$ crude protein) at $1 \mathrm{~kg}$ for every $3 \mathrm{~kg}$ milk yield $\mathrm{d}^{-1}$. Cows were milked twice daily at approximately equal intervals at 5.00 to 6.00 hours and 16.00 to 17.00 hours.

Average days in lactation for sampled cows were 1 to 40 in early lactation, 50 to 90 at peak lactation and 140 to 180 in mid-lactation. Blood samples (one sample per animal) were obtained via the jugular vein. To minimise the effect of diurnal variations, they were taken from all cows at the same time of the day, between 8.00 and 9.00 hours.

Samples were kept at room temperature for complete clotting and then were centrifuged for the separation of serum. The serum was then decanted and stored in vials at $-20^{\circ} \mathrm{C}$ until analysed.

Thyroxine and triiodothyronine in serum were determined in duplicate by radioimmunoassay using ${ }^{125} \mathrm{I}_{-} \mathrm{T}_{4}$ RIA (PEG) and ${ }^{125} \mathrm{I}_{-} \mathrm{T}_{3}$ RIA (PEG) kits provided by the Institute of Isotopes of the Hungarian Academy of Science. Milk yield was recorded during the morning and afternoon milkings by Milkoscope MK II (Foss Electric, Denmark).

Statistics were carried out using Statmost package on Windows. The study was designed to allow one-way analysis of variance (ANOVA) to assess the effect of the stage of lactation on serum $T_{4}$ and $T_{3}$ levels. The data for $T_{4}, T_{3}$ and milk yield (mean \pm standard error of the mean [SEM]) were then subjected to Student's $t$-test. The level of statistical significance was pre-set at $P<0.05$.

\section{RESULTS}

The average milk yield was significantly higher at peak lactation than in early $(P<0.01)$ and in mid $(P<0.001)$ lactation (table I).

The one-way ANOVA indicated that both $\mathrm{T}_{4}$ and $\mathrm{T}_{3}$ were affected $(P<0.01)$ by the stage of lactation. Serum concentrations of $T_{4}$ and $T_{3}$ were variable but on average they changed little between animals $(P>0.05)$ within the stages of lactation. $\mathrm{T}_{4}$ ranged from 32.45 to $39.81 \mathrm{nmol} \cdot \mathrm{L}^{-1}, 35.24$ to $42.63 \mathrm{nmol} \cdot \mathrm{L}^{-1}$ and 47.22 to $53.0 \mathrm{nmol} \cdot \mathrm{L}^{-1}$ in early, at peak and in mid-lactation, respectively. At the same time, $\mathrm{T}_{3}$ varied between 0.92 to $1.21 \mathrm{nmol} \cdot \mathrm{L}^{-1}, 1.24$ and $1.64 \mathrm{nmol} \cdot \mathrm{L}^{-1}$ and 1.91 and $2.35 \mathrm{nmol} \cdot \mathrm{L}^{-1}$, respectively. Mean serum concentrations of $\mathrm{T}_{4}$ and $\mathrm{T}_{3}$ in early and at peak lactation were significantly $(P<0.001)$ lower than the levels in midlactation (table $I$ ). There were no differences 
Table I. Mean \pm standard error of the mean $(\mathrm{SEM})$ for milk yield, thyroxine $\left(\mathrm{T}_{4}\right)$ and triiodothyronine $\left(\mathrm{T}_{3}\right)$ in early, at peak and in mid-lactation in dairy cows.

\begin{tabular}{lccc}
\hline & \multicolumn{3}{c}{ Stages of lactation } \\
\cline { 2 - 4 } & $\begin{array}{c}\text { Early } \\
(1-40 \text { days })\end{array}$ & $\begin{array}{c}\text { Peak } \\
(50-90 \text { days })\end{array}$ & $\begin{array}{c}\text { Mid } \\
(140-180 \text { days })\end{array}$ \\
\hline Milk yield $(\mathrm{kg})$ & $24.5 \pm 1.3^{\mathrm{a}}$ & $29.7 \pm 0.9^{\mathrm{c}}$ & $21.5 \pm 0.8^{\mathrm{d}}$ \\
$\mathrm{T}_{4}\left(\mathrm{nmol} \cdot \mathrm{L}^{-1}\right)$ & $35.51 \pm 1.84^{\mathrm{a}}$ & $39.12 \pm 1.81^{\mathrm{a}}$ & $49.63 \pm 1.41^{\mathrm{b}}$ \\
$\mathrm{T}_{3}\left(\mathrm{nmol} \cdot \mathrm{L}^{-1}\right)$ & $1.12 \pm 0.13^{\mathrm{a}}$ & $1.43 \pm 0.10^{\mathrm{a}}$ & $2.0 \pm 0.12^{\mathrm{b}}$
\end{tabular}

Means on the same row with different superscripts differ: ${ }^{\mathrm{a}-\mathrm{d}} P<0.05 ;{ }^{\mathrm{a}-c} P<0.01 ;{ }^{\mathrm{a}-\mathrm{b}}, \mathrm{c}-\mathrm{d} P<0.001$.

in mean $\mathrm{T}_{4}$ and $\mathrm{T}_{3}$ values between early and peak lactation.

The circulating $T_{4}$ and $T_{3}$ were negatively correlated with milk yield for each stage of lactation.

\section{DISCUSSION}

One-way ANOVA revealed a significant effect of the stage of lactation on serum $\mathrm{T}_{4}$ and $\mathrm{T}_{3}$. There were significantly lower thyroid hormone levels in early and at peak lactation than in mid-lactation, when milk production markedly decreased. It might be suggested that the low serum thyroid hormone levels in early and at peak lactation in our study are a consequence of an adaptive decrease in production and secretion rate of $T_{4}$ and altered $T_{4}$ to $T_{3}$ conversion in extrathyroidal tissues. The depression of thyroid secretion rate in the early stages of lactation is presumably due to the insufficient fuel supply to non-mammary tissues because of the nutrient consumption by the intensively lactating mammary gland and to the apparent energy deficiency state during the period of highest lactational performance. Previously results obtained in our laboratory $[5,9]$ indicated that in the period of 1-80 days of lactation the high yielding cows exhibited lower serum concentrations of $T_{4}$ and $T_{3}$ and higher values of the ratio $\mathrm{T}_{4}: \mathrm{T}_{3}$ than the low yielding cows, suggesting differences in thyroid hormone metabolism, associated with milk secretion intensity.

The inverse relationship between the changes in serum concentrations of $T_{4}, T_{3}$ and milk yield could be in part ascribed to the large demand for these hormones by the intensively lactating mammary gland and to their increased rate of metabolism in mammary tissue during the first months of lactation, when milk yields rapidly rise and reach peak values. Recently, it has been found that an enhanced conversion of thyroxine to triiodothyronine in the mammary gland, but not in other organs $[1,6]$, was favourable for a high milk yield in dairy cows. This indicates organ-specific changes in $\mathrm{T}_{3}$ generation, which is essential to support metabolic demands of lactation [6].

The increased thyroid secretion rate in early lactation is unfavourable for physiological adjustment to high lactational performance because some of the milk precursors, especially glucose, will be directed to the extra-mammary tissues, e.g. adipose tissue, muscles, etc. The reduced serum thyroid hormone levels associated with the low insulin concentration in this period [7] promote the preferential utilisation of substrates by the mammary gland. 


\section{CONCLUSION}

The reduction of serum $T_{4}$ and $T_{3}$ in early and at peak lactation is probably a reflection of the decreased thyroid hormone secretion rate due to the energy deficiency state as well as to the large demand for these hormones by the mammary gland, when cows are producing considerable quantities of milk. Therefore, the significantly lower thyroid hormone levels in early and at peak lactation compared to those in mid-lactation could be explained by a physiological adaptation to lactation. The results of the present experiment are consistent with the metabolic priority of the mammary gland and shift in partitioning of nutrients characteristic of lactation.

\section{REFERENCES}

[1] Blum J., Endokrinologie und Tierproduktion, Schweiz. Arch. Tierheilk. 134 (1992) 213-229.

[2] Collier R., McNamara J., Wallace C., Dehoff M., A review of endocrine regulation of metabolism during lactation, J. Anim. Sci. 59 (1984) 498-510.

[3] Convey E., Thomas J., Tucker H., Gill J., Effect of thyrotropin-releasing hormone on yield and composition of bovine milk, J. Dairy Sci. 56 (1973) 484-486.

[4] Davis S., Collier R., McNamara J., Head H., Croom W., Wilcox C., Effect of thyroxine and growth hormone treatment of dairy cows on mammary uptake of glucose, oxygen and other milk fat precursors, J. Anim. Sci. 66 (1988) 80-89.

[5] Gueorguiev I., Correlation between the serum concentration of thyroid hormones and the milk productivity of high and low productive cows, Vet. Sci. 27 (1993) 44-48.

[6] Kahl S., Remsey T., Elsasser T., Extrathyroidal 5 '-deiodinase activity in cattle; relationship to growth and hormones involved in nutrient partitioning, in: Satellite Conference of the Eighth International Conference on Production Diseases in Farm Animals on Nutrition Related Endocrine Changes in Cattle at the School of Veterinary Medicine, Bern, 29 August 1992. University of Bern, Switzerland, 1992, p. 9 (Abstr.).

[7] Koprowski J., Tucker H., Bovine serum growth hormone, corticoids and insulin during lactation, Endocrinology 93 (1973) 645-651.

181 Lapierre H., Petitclerc D., Pelletier G., Delorme L., Dubreuil P., Morisset J., Gaudreau P., Couture Y., Brazeau P., Effect of growth hormone releasing factor and (or) thyrotropin releasing factor on hormone concentrations and milk production in dairy cows, Can. J. Anim. Sci. 70 (1990) 175-189.

[9] Pentchev I., Dynamics of the thyroid hormones related to the birth act and lactation of high- and low productive cows, Vet. Sci. 27 (1993) 53-59.

[10] Tiirats T., Thyroxine, triiodothyronine and reverse-triiodothyronine concentrations in blood plasma in relation to lactational stage, milk yield, energy and dietary protein intake in Estonian dairy cows, Acta. Vet. Scand. 38 (1997) 339-348.

[11] Wilson D., Gorewit R., Specific thyroxine receptors in mammary cytosol from lactating cattle, Biochem. Biophys. Res. Comm. 95 (1980) $807-815$. 